\title{
Pengaruh Kompres Hangat Rebusan Air Serai Terhadap Penurunan Nyeri Arthritis Rheumatoid Pada Lansia di Panti Sosial Tresna Werdha Budi Sejahtera Banjarbaru Provinsi Kalimantan Selatan
}

\author{
Yurida Olviani*, Erna Lidia Sari** \\ Fakultas Keperawatan dan Ilmu Kesehatan \\ Universitas Muhammadiyah Banjarmasin \\ e-mail : yuridaolviani@gmail.com
}

DOI: $10.33859 / \mathrm{dksm} . v 11 \mathrm{i1} .536$

\begin{abstract}
ABSTRAK
Latar Belakang: Arthritis Rheumatoid merupakan penyakit muskuloskeletal yang sering terjadi pada usia lanjut. Gangguan pada system muskuloskeletal yang ditandai dengan munculnya nyeri sendi dan kekakuan yang mengakibatkan penurunan kemampuan fisiologis atau kualitas hidup lansia. Manajemen nyeri bisa dilakukan dengan farmakologi dan nonfarmakologi, salah satu intervensi non farmakologi yaitu dengan melakukan kompres serai hangat. Tanaman serai mengandung minyak atsiri yang memiliki sifat pedas dan bersifat hangat sebagai anti radang dan menghilangkan rasa sakit atau nyeri.

Tujuan: untuk mengetahui pengaruh kompres hangat rebusan air serai terhadap penurunan nyeri Arthritis Rheumatoid pada lansia di Panti Sosial Tresna Werdha Budi Sejahtera Banjarbaru.

Metode: Rancangan penelitian menggunakan pre-eksperimental design dengan one group pretestpostest pada 30 responden lansia yang memenuhi kriteria inklusi dan ekslusi menggunakan metode purposive sampling. Instrumen penelitian menggunakan waslap dan lembar observasi Numeric Rating Scale (NRS).

Hasil: Hasil penelitian dapat diketahui dari 30 responden sebelum diberikan kompres serai mengeluh nyeri pada kategori sedang $(83,3 \%)$, setelah diberikan kompres serai mengeluh nyeri pada kategori ringan $(83,3 \%)$. Berdasarkan analisis menggunakan uji Wilcoxon menunjukkan $p$ value sebesar 0,000 nilai tersebut secara statistik bermakna $(\mathrm{p}<0,05)$.

Simpulan: Berdasarkan hasil penelitian menunjukan bahwa ada pengaruh kompres serai terhadap penurunan intensitas nyeri Arthritis Rheumatoid pada lansia.

Kata Kunci : Arthritis Rheumatoid, Kompres Serai Hangat. Usia Lanjut,
\end{abstract}




\section{Abstract}

Background: Rheumatoid arthritis is a musculoskeletal disease that often occurs in the elderly. Disorders of the musculoskeletal system, characterized by joint pain and stiffness that result in decreased physiological abilities or quality of life in the elderly. Pain management can be done with pharmacology and non-pharmacology, one of the non-pharmacological interventions is to do warm lemongrass compresses. Lemongrass contains essential oils which have spicy and warm properties as anti-inflammatory and relieve pain or aches.

Objective: to determine the effect of warm compresses boiled lemongrass water on the reduction of Rheumatoid Arthritis pain in the elderly at the Tresna Werdha Budi Sejahtera Social Home, Banjarbaru.

Methods: The research design used pre-experimental design with one group pretest-postest on 30 elderly respondents who met the inclusion and exclusion criteria using purposive sampling method. The research instrument used a washcloth and the Numeric Rating Scale (NRS) observation sheet.

Results: The results of the study can be seen from 30 respondents before being given lemongrass compresses complaining of pain in the moderate category (83.3\%), after being given lemongrass compresses complained of pain in the mild category (83.3\%). Based on the analysis using the Wilcoxon test, it shows a p value of 0.000 , this value is statistically significant $(p<0.05)$.

Conclusion: Based on the results of the study, it shows that there is an effect of lemongrass compresses on reducing the intensity of Rheumatoid Arthritis pain in the elderly.

Keywords: Elderly, Rheumatoid Arthritis, Warm Lemongrass Compress.

\section{PENDAHULUAN}

Lanjut usia (lansia) merupakan dimana seseorang telah mencapai usia 65 tahun ke atas. Lansia bukan penyakit namun merupakan tahap lanjut dari suatu proses kehidupan yang ditandai dengan penurunan kemampuan tubuh untuk beradaptasi dengan stress lingkungan.

Pada lansia sistem muskuloskletal akan mengalami beberapa perubahan seperti perubahan pada jaringan penghubung (kolagen dan elastin), berkurangnya kemampuan kartilago untuk bergerasi, kepadatan tulang berkurang, perubahan struktur otot, dan terjadi penurunan elastisitas sendi (Black Joyce M, 2014).
Salah satu penyakit yang sering diderita pada lansia adalah penyakit Arthritis Rheumatoid, yaitu suatu penyakit yang menyerang autoimun dimana persendian (tangan dan kaki), secara simetris mengalami peradangan, sehingga terjadi pembengkakan nyeri dan dapat menyebabkan kerusakan pada bagian dalam sendi (Handriani, 2011).

$$
\text { Lanjut usia dengan Arthritis }
$$

Rheumatoid akan mengeluh nyeri punggung kronis, kelemahan otot, penurunan tinggi badan, penurunan mobilitas dan nyeri sendi (Dewi, 2014). Keluhan nyeri biasanya timbul karena melakukan aktivitas fisik, nyeri juga timbul karena istirahat yang tidak ada hubungannya dengan masa gerakan, atau pada 
pagi hari ketika bangun tidur. (Hembing, 2009). Tingginya angka kejadian Arthritis Rheumatoid dipengaruhi oleh banyak faktor yaitu usia, jenis kelamin, genetik, hormon seks, serta imunitas (Nugroho, 2014).

Menurut World Health Organization (WHO) pada tahun 2016 sebanyak 335 juta penduduk di dunia yang mengalami Rheumatoid Arthritis (Bawarodi \& Malara, 2017). Sedangkan menurut Arthritis Foundation pada tahun 2015, sebanyak $22 \%$ atau lebih dari 50 juta orang dewasa di Amerika Serikat berusia 18 tahun atau lebih di diagnosa Arthritis. Dari data tersebut, sekitar $3 \%$ atau 1,5 juta orang dewasa mengalami Arthritis Rheumatoid. (Chabib, dkk, 2016)

Di Indonesia prevelensi Arthritis Rheumatoid pada tahun 2004 mencapai angka 2 juta jiwa, dengan angka perbandingan pasien wanita tiga kali lipatnya dari laki-laki. Jumlah penderita Arthritis Rheumatoid di Indonesia pada tahun 2011 diperkirakan prevelensinya mencapai $29,35 \%$, pada tahun 2012 prevelensinya sebanyak 39,47\%, dan tahun 2013 prevelensinya sebanyak 45,59\%. (Bawarodi \& Malara 2017)

Menurut Agoes dkk (2017), terapi Arthritis Rheumatoid dibedakan menjadi dua, yaitu terapi farmakologis dan nonparmakologis. Terapi farmakologis penyakit radang sendi berupa pemberian analgetik, antiimflamasi non-steroid, kortikosteroid, dan obat anti Rheumatoid. Sedangkan Salah satu tindakan yang terbukti efektif untuk mengurangi nyeri secara non-farmakologi adalah dengan menghangatkan persendian yang sakit (Pratintya, 2012). Kompres adalah suatu metode penggunaan suhu hangat setempat yang menimbulkan beberapa efek fisiologi. Kompres hangat dapat digunakan pada pengobatan nyeri dan mereleksasikan otot-otot yang tegang. (Wurangian, 2014)

Tanaman yang memiliki zat sebagai penghangat, anti radang dan dapat memperlancarkan aliran darah seperti serai. Pengolahannya sederhana seperti dengan kompres serai hangat. Cara ini merupakan alternatif yang dapat dilakukan secara mandiri dan mempunyai resiko yang rendah. Dalam buku herbal Indonesia disebutkan bahwa khasiat tanaman serai mengandung minyak atsiri yang memilki sifat kimiawi dan efek farmakalogi yaitu rasa pedas dan bersifat hangat sebagai anti radang dan menghilangkan rasa sakit yang bersifat analgesik serta melancarkan sirkulasi darah dan diindikasikan untuk mengurangi nyeri sendi, nyeri otot, badan pegelinu dan sakit kepala. (Hidayat \& Napitupilu, 2015)

Berdasarkan hasil studi pendahuluan yang dilakukan oleh peneliti di Panti Werdha Tresna Budi Sejahtera Banjarbaru melalui wawancara terhadap 10 orang lansia yang mengeluh nyeri sendi Arthritis Rheumatoid, 4 orang dari mereka biasanya menggunakan obat penghilang nyeri yang diberikan petugas 
Dinamika Kesehatan Jurnal Kebidanan dan Keperawatan Vol 11 No. 1 Juli 2020 ( ISSN: 2086-3454 EISSN: 2549-4058)

url: http://ojs.dinamikakesehatan.unism.ac.id DOI : https://doi.org/10.33859/dksm.v11il

Pengaruh Kompres Hangat Rebusan Air Serai Terhadap Penurunan Nyeri Arthritis Rheumatoid Pada Lansia di Panti Sosial Tresna Werdha Budi Sejahtera Banjarbaru Provinsi Kalimantan Selatan

panti, 4 orang menggunakan balsam atau minyak gosok dan 2 orang hanya membiarkan rasa nyeri tersebut. Dari uraian tersebut peneliti tertarik untuk melakukan penelitian tentang pengaruh kompres hangat rebusan air serai terhadap penurunan nyeri Arthritis Rheumatoid pada lansia.

Tujuan dari penelitian ini adalah untuk menganalisis pengaruh kompres hangat rebusan air serai terhadap penurunan nyeri Arthritis Rheumatoid pada lansia di Panti sosial Tresna Werdha Budi Sejahtera Banjarbaru Provinsi Kalimantan Selatan Tahun 2019.

\section{METODE}

Penelitian ini dilakukan di Panti Sosial Tresna Werdha Budi Sejahtera Banjarbaru Provinsi Kalimantan Selatan. Jenis penelitian ini adalah pre-eksperimental design dengan one group pretest-postest. Populasi pada penelitian ini adalah seluruh lansia di Panti Sosial Tresna Werdha Budi Sejahtera Banjarbaru yang berjumlah 111 lansia. Pengambilan sampel pada penelitian ini dilakukan dengan metode purposive sampling. Jumlah sampel pada penelitian ini adalah 30 responden yang memenuhi kriteria inklusi dan eksklusi.

Instrumen yang digunakan pada penelitian ini berupa waslap yang digunakan untuk melakukan kompres hangat rebusan air serai serta lembar observasi Numerical Rating
Scale (NRS). Analisa data menggunakan analisa univariate dan bivariate. Analisa univariate pada penelitian ini adalah skala nyeri sebelum perlakuan dan skala nyeri setelah perlakuan kompres hangat rebusan air serai. Dan analisis bivariate dalam penelitian ini menggunakan uji Wilcoxon.

\section{HASIL}

\section{a. Karakteristik responden berdasarkan usia}

Tabel 1 Distribusi frekuensi responden berdasarkan usia

\begin{tabular}{ccc}
\hline Usia & Frekuensi & Persentase \\
\hline $60-74$ & 27 & 90 \\
$75-90$ & 3 & 10 \\
$>90$ & 0 & 0 \\
\hline Jumlah & 30 & 100 \\
\hline
\end{tabular}

Tabel 1 menunjukkan bahwa lansia yang mendapatkan kompres hangat rebusan air serai berdasarkan kategori umur paling banyak yaitu umur 60-74 tahun sebanyak 27 responden $(90 \%)$

\section{b. Karakteristik responden berdasarkan jenis kelamin}

Tabel 2 Distribusi frekuensi responden berdasarkan jenis kelamin

\begin{tabular}{ccc}
\hline $\begin{array}{c}\text { Jenis } \\
\text { Kelamin }\end{array}$ & Frekuensi & Persentase \\
\hline Laki-laki & 11 & 90 \\
Perempuan & 19 & 10 \\
\hline Jumlah & 30 & 100 \\
\hline
\end{tabular}

Tabel 2 menunjukkan bahwa jumlah lansia berjenis kelamin perempuan lebih banyak menderita Arthritis Rheumatoid dibandingkan laki-laki yaitu sebanyak 19 responden $(63,3 \%)$. 


\section{c. Karakteristik responden berdasarkan riwayat pekerjaan}

Tabel 3 Distribusi frekuensi responden berdasarkan riwayat pekerjaan

\begin{tabular}{ccc}
\hline Pekerjaan & Frekuensi & Persentase \\
\hline IRT & 13 & 43,4 \\
Swasta & 10 & 33,3 \\
Pedagang & 7 & 23,3 \\
\hline Jumlah & 30 & 100
\end{tabular}

Tabel 3 menunjukkan bahwa sebagian responden bekerja sebagai (Ibu rumah tangga) IRT yaitu sebanyak 13 responden (43,3\%).

\section{Analisa Univariat}

a. Skala nyeri responden sebelum intervensi kompres hangat rebusan air serai

Tabel 4 Distribusi frekuensi skala nyeri responden sebelum intervensi kompres hangat rebusan air serai

\begin{tabular}{ccc}
\hline $\begin{array}{c}\text { Kategori } \\
\text { Nyeri }\end{array}$ & Frekuensi & Persentase \\
\hline Tidak Nyeri & 0 & 0 \\
Nyeri & 0 & 0 \\
Ringan & & \\
Nyeri & 25 & 83,3 \\
Sedang & & \\
Nyeri Berat & 5 & 16,7 \\
Jumlah & 30 & 100 \\
\hline
\end{tabular}

Tabel 4 menunjukkan bahwa sebagian besar skala nyeri responden sebelum diberikan kompres hangat rebusan air serai adalah skala nyeri sedang yaitu sebanyak 25 responden $(83,3 \%)$.

\section{b. Skala nyeri responden setelah intervensi kompres hangat rebusan air serai}

Tabel 5 Distribusi frekuensi skala nyeri responden setelah diberikan intervensi kompres hangat rebusan air serai

\begin{tabular}{ccc}
\hline $\begin{array}{c}\text { Kategori } \\
\text { Nyeri }\end{array}$ & Frekuensi & Persentase \\
Tidak Nyeri & 0 & 0 \\
Nyeri & 25 & 83,3 \\
Ringan & & \\
Nyeri & 0 & 0 \\
Sedang & & \\
Nyeri Berat & 5 & 16,7 \\
Jumlah & 30 & 100 \\
\hline
\end{tabular}

Tabel 5 menunjukkan bahwa sebagian besar skala nyeri responden setelah diberikan kompres hangat rebusan air serai adalah skala nyeri ringan yaitu sebanyak 25 responden $(83,3 \%)$.

\section{Analisa Bivariat}

Tabel 6 Pengaruh kompres hangat rebusan air serai terhadap keluhan nyeri Arthritis Rheumatoid pada lansia di Panti Sosial Tresna Werdha Budi Sejahtera Banjarbaru

\begin{tabular}{|c|c|c|c|c|}
\hline & & $\begin{array}{c}\text { Median } \\
\text { (min-max) }\end{array}$ & Rerata \pm s.b. & $\mathbf{P}$ \\
\hline Pre & 30 & $\begin{array}{c}6 \\
(4-9)\end{array}$ & $5.80 \pm 1.297$ & 0,000 \\
\hline Post & 30 & $\begin{array}{c}3 \\
(2-8)\end{array}$ & $3,57 \pm 1.695$ & \\
\hline
\end{tabular}

\section{Sumber : Uji Wilcoxon}

Berdasarkan Tabel 6 dapat dilihat adanya perbedaan yang signifikan antara sebelum dan setelah diberikan intervensi kompres hangat rebusan air serai. Hasil uji statistik didapatkan nilai kompres hangat rebusan air serai $p$ value 
Dinamika Kesehatan Jurnal Kebidanan dan Keperawatan Vol 11 No. 1 Juli 2020 ( ISSN: 2086-3454 EISSN: 2549-4058)

url: http://ojs.dinamikakesehatan.unism.ac.id DOI : https://doi.org/10.33859/dksm.v11il

Pengaruh Kompres Hangat Rebusan Air Serai Terhadap Penurunan Nyeri Arthritis Rheumatoid Pada Lansia di Panti Sosial Tresna Werdha Budi Sejahtera Banjarbaru Provinsi Kalimantan Selatan

0,000 berarti $\alpha<0,05$, sehingga dapat disimpulkan kompres hangat rebusan air serai berpengaruh terhadap penurunan nyeri Arthritis Rheumatoid.

\section{PEMBAHASAN}

\section{Intensitas nyeri Arthritis Rheumatoid} sebelum diberikan intervensi kompres hangat rebusan air serai.

\section{a. Karakteristik responden berdasarkan} usia

Berdasarkan hasil penelitian nyeri Arthritis Rheumatoid yang terjadi pada lansia di Panti Sosial Tresna Werdha (PSTW) Budi Sejahtera Banjarbaru sebelum diberi perlakuan kompres hangat rebusan air serai didapatkan data dari 30 responden mengeluh nyeri pada kategori skala nyeri sedang yaitu sebanyak 25 responden $(83,3 \%)$ dan skala nyeri berat sebanyak 5 responden $(16,7 \%)$. Pada penelitian ini sebagian besar responden berusia 60-74 tahun (90\%).

Menurut asumsi peneliti usia lanjut cenderung akan mengalami penurunan aktivitas karena terjadinya penurunan fungsi tubuh akibat proses penuaan. Organ-organ tubuh yang dulunya berfungsi dengan baik tanpa adanya gangguan, sekarang mengalami kemunduran karena proses penuaan. Hal ini sesuai dengan teori yang dikemukakan oleh Handayani (2015) bahwa lansia berusia 60-74 tahun lebih banyak mengalami masalah kesehatan karena pada usia ini mereka memasuki tahap awal sebagai lansia, mereka memerlukan penyesuaian yang lebih terhadap perubahan-perubahan baik fisik maupun kognitif yang terjadi pada diri mereka. Secara biologis proses penuaan secara terus menerus yang ditandai dengan menurunnya daya tahan tubuh.

\section{b. Karakteristik responden berdasarkan jenis kelamin}

Dalam penelitian ini sebagian besar responden berjenis kelamin perempuan yaitu sebanyak 19 responden (63,3\%). Menurut peneliti perempuan lebih sering terkena Arthritis Rhematoid disebabkan karena penurunan hormon estrogen yang bisa mengakibatkan tubuh mudah rapuh dan kekuatannya berkurang. Hormon estrogen sangat penting untuk menjaga kepadatan tulang. Kekurangan hormon estrogen mengakibatkan lebih banyak penghancuran tulang dari pada pembentukan tulang. Keadaan ini mempercepat dan memperberat penyakit Arthritis Rheumatoid. Hal ini sesuai dengan teori yang dikemukakan oleh Dugowson (2009), bahwa perempuan lebih sering terkena Arthritis Rhematoid pada lutut dan sendi, dan laki-laki lebih sering terkena Arthritis Rhematoid di paha, lutut dan sendi. Arthritis Rhematoid lebih banyak pada perempuan dari pada pria hal ini menunjukkan adanya peran horomonal pada pathogenesis Arthritis Rhematoid 


\section{c. Karakteristik responden berdasarkan riwayat pekerjaan}

Berdasarkan karakteristik pekerjaan pada sampel penelitian ini sebagian besar adalah IRT sebanyak 13 responden $(43,3 \%)$. Menurut peneliti angka keterpaparan penyakit Artritis berhubungan dengan aktivitas seseorang. Ibu rumah tangga umumnya melakukan banyak kegiatan dirumah yang dapat mengakibatkan banyaknya pergerakan pada sendi seperti menyetrika, memasak naik turun tangga atau berdiri dan jongkok pada saat mencuci, berkebun atau melakukan pekerjaan rumah lainnya dan ketika ditanyakan tidak ada dari mereka yang memiliki asisten rumah tangga untuk menyelesaikan pekerjaan rumah tersebut, sehingga mereka terbiasa untuk melakukan semuanya sendiri. Sehingga dari hasil tersebut dapat diketahui bahwa pekerjaan yang berat berpengaruh terhadap penyakit Arthritis Rheumatoid. Hal ini sesuai dengan teori yang dikemukankan oleh Bawarodi dkk (2017), bahwa Pekerjaan adalah salah satu dari faktor yang dapat memicu timbulnya penyakit sendi.

\section{Intensitas nyeri Arthritis Rheumatoid} setelah intervensi kompres hangat rebusan air serai.

Berdasarkan hasil penelitian nyeri Arthritis Rheumatoid yang terjadi pada lansia di Panti Sosial Tresna Werdha Budi Sejahtera Banjarbaru setelah diberikan intervensi kompres hangat rebusan air serai didapatkan data dari 30 responden sebagian besar mengalami penurunan skala nyeri pada kategori skala nyeri ringan sebanyak 25 responden $(83,3 \%)$.

Menurut peneliti perbedaan antara skala nyeri sebelum dan sesudah pemberian kompres hangat ini terjadi karena responden diberikan perlakuan kompres hangat rebusan air serai dengan cara merebus daun serai setelah itu air rebusan serai di kompreskan ke bagian yang mengalami nyeri Arthritis Rheumatoid dan responden dapat mengurangi rasa nyeri tanpa meminum obat karena serai bersifat anti inflamasi sehingga dapat mengurangi nyeri Pemberian air hangat memberikan rasa hangat pada seseorang dengan menggunakan cairan atau alat yang dapat memindahkan panas ketubuh sehingga dapat melancarkan aliran darah, mengurangi rasa sakit dan memberikan rasa nyaman dan meningkatkan aliran darah ke daerah sendi, dengan begitu proses radang dapat dikurangi dan sendi dapat berfungsi secara maksimal. Selain itu ditambah dengan serai yang mengandung minyak atrisi yang bersifat panas, yang dapat mengurangi proses radang. Hal ini sesuai dengan teori yang dikemukakan oleh Wurangian (2014), bahwa kompres hangat sendiri mempunyai dampak fisiologis yaitu dapat melunakan jaringan fibrosa, membuat otot tubuh lebih rileks, menurunkan atau menghilangkan rasa nyeri, 
Dinamika Kesehatan Jurnal Kebidanan dan Keperawatan Vol 11 No. 1 Juli 2020 ( ISSN: 2086-3454 EISSN: 2549-4058)

url: http://ojs.dinamikakesehatan.unism.ac.id DOI : https://doi.org/10.33859/dksm.v11il

Pengaruh Kompres Hangat Rebusan Air Serai Terhadap Penurunan Nyeri Arthritis Rheumatoid Pada Lansia di Panti Sosial Tresna Werdha Budi Sejahtera Banjarbaru Provinsi Kalimantan Selatan

dan memperlancar aliran darah. Rasa panas yang ditimbulkan dari kompres hangat dapat mengakibatkan dilatasi dan terjadi perubahan fisiologis sehingga dapat melancarkan peredaran darah dan meredakan nyeri.

\section{Pengaruh pemberian kompres hangat rebusan air serai terhadap keluhan nyeri Arthritis Rheumatoid.}

Sebelum diberikan kompres hangat rebusan air serai terdapat responden yang mengalami skala nyeri sedang sebanyak 25 responden $(83,3 \%)$, dan skala nyeri berat sebanyak 5 responden $(16,7 \%)$. Setelah diberikan kompres hangat rebusan air serai terdapat 25 responden $(83,3 \%)$ yang mengalami penurunan skala nyeri sedang ke skala nyeri ringan, sedangkan pada skala nyeri berat sebanyak 5 responden $(16,7 \%)$, tidak mengalami penurunan skala nyeri. Berdasarkan hasil analisis data menunjukan bahwa ada perbedaan yang signifikan ( $\mathrm{p}$ value 0,000) hal ini berarti nilai $\alpha<0,05$ menunjukan bahwa ada perbedaan antara sebelum dan setelah diberikan intervensi kompres kompres hangat rebusan air serai terhadap nyeri Arthritis Rheumatoid pada lansia di Panti Sosial Tresna Werdha (PSTW) Budi Sejahtera Banjarbaru.

Menurut teori yang dikemukakan oleh lukman dan Ningsih (2011), penatalaksanaan untuk menghilangkan nyeri dan peradangan, mempertahankan fungsi sendi dan kemampuan maksimal serta mencegah atau memperbaiki deformitas yang terjadi pada sendi, salah satu tindakan yang bisa dilakukan yaitu dengan kompres air hangat. Pemberian air hangat memberikan rasa hangat pada seseorang dengan menggunakan cairan atau alat yang dapat memindahkan panas ketubuh sehingga dapat melancarkan aliran darah, mengurangi rasa sakit dan memberikan rasa nyaman serta meningkatkan aliran darah ke daerah sendi sehingga proses radang dapat dikurangi dan sendi dapat berfungsi secara maksimal. Selain itu ditambah dengan serai yang mengandung minyak atsiri yang bersifat panas, yang dapat mengurangi peradangan.

Serai mengandung minyak atsiri, yang berkhasiat sebagai analgesik, somatik dan aromatik. Penambahan campuran serai dalam terapi kompres hangat dapat lebih meningkatkan terjadinya penurunan nyeri. Kompres serai (Cymbopogon citratus) hangat dapat memperbaiki peredaran darah didalam jaringan dan pelebaran pembuluh darah, aktifitas sel yang meningkat akan mengurangi rasa sakit.

Menurut asumsi peneliti kandungan tanaman serai yaitu minyak atsiri yang memiliki rasa pedas dan bersifat hangat sebagai anti radang (anti inflamasi), sehingga dengan panasnya tersebut dapat melancarkan aliran darah yang akan meningkatkan suplai oksigen ke jaringan, sel-sel mendapatkan oksigen sehingga dapat mengurangi rasa 
nyeri. Dengan adanya pengaruh kompres hangat rebusan air serei terhadap penurunan intensitas nyeri Arthritis Rheumatoid pada lanjut usia, maka terapi kompres serei ini dapat diterapkan atau dapat dijadikan salah satu pengobatan alternatif untuk mengatasi nyeri pada penderita Arthritis Rheumatoid.

\section{KESIMPULAN}

a. Sebagian besar responden sebelum diberikan intervensi kompres hangat rebusan air serai mengeluh nyeri pada kategori sedang sebanyak 25 responden $(83,3 \%)$

b. Sebagian besar responden setelah diberikan intervensi kompres kayu manis mengalami penurunan nyeri pada kategori nyeri ringan sebanyak 25 responden $(83,3 \%)$

C. Adanya pengaruh sebelum dan setelah pemberian kompres hangat rebusan air serai terhadap keluhan nyeri Arthritis Rheumataoid.

\section{SARAN}

a. Bagi Tempat Penelitian

Hasil penelitian ini diharapkan memberikan kontribusi dan masukan bagi petugas kesehatan panti untuk menggunakan hasil penelitian ini sebagai salah satu terapi komplementer dalam meningkatkan kualitas pelayanan terhadap lansia.

\section{b. Bagi Lansia}

Agar selalu menjaga kesehatannya dengan mengurangi aktivitas berat karena efek dari kompres hangat rebusan air serai tidak akan terus berespon jika lansia mengalami nyeri Arthritis Rheumatoid secara terus menerus.

c. Bagi Peneliti Selanjutnya

Peneliti selanjutnya dapat meneliti lebih lanjut terkait terapi pemberian kompres hangat rebusan air serai dengan mempertimbangkan karakteristik lansia yang sama dan perlu diuji laboratorium secara invivo untuk melihat efek tanaman serai terhadap nyeri Arthritis Rheumatoid.

\section{DAFTAR PUSTAKA}

Azwar Agoes, dkk. (2017). Penyakit di usia tua. Jakarta : ECG

Black Joyce M. (2014). Keperawatan medikal bedah. Jakarta : Elsevier

Bawarodi, F., J., \& Malara, R. T. (2017). Faktor-faktor yang berhubungan dengan kekambuhan penyakit Rematik di wilayah Puskesmas Beo Kabupaten Talaud. Jurnal Keperawatan. Diperoleh pada tanggal 20 Juni 2019 dari https://ejournal.unsrat.ac.id

Dewi, R.S. (2014). Keperawatan gerontik. Yogyakarta: Deepublish

Dugowson. (2009). Arthritis and allied condition: Texbook of Rhemathology. Pennsylvania: A Waverly Company.

Hidayat, S. \& Napitupulu, R. (2015). Kitab tumbuhan obat. Jakarta: Penebar Swadaya 
Handayani, A. (2015). Pemanfaatan tumbuhan berkhasiat obat oleh masyarakat sekitar Cagar Alam Gunung Simpang, Jawa Barat. In Prosiding Seminar Nasional Masyarakat Biodiversitas Indonesia. dari

https://biodiversitas.mipa.uns.ac.id

Hembing, W. (2009). Atasi asam urat dan Rematik ala Hembing. Jakarta :Puspa Swara

Handriani. (2011). Kesehatan gaya hidup modern bisa disebabkan Reumatik. Diakses 22 Juni 2019

Lukman \& Ningsih. (2011). Asuhan keperawatan pada klien dengan gangguan sistem musculoskeletal. Jakarta : Selemba Medika

Lutfi Chabib, dkk. (2016). Review Rheumatoid Arthritis: terapi farmakologi, potensi kurkumin dan analognya, serta pengembangan system nano partikel. Jurnal Pharmascience, Vol 3, Nomor 1. Yogyakarta

Nugroho Wahyudi. (2014). Keperawatan gerontik dan geriatrik Edisi 3. Jakarta : ECG

Pratintya, A. D., \& Harmilah, H. (2012). Pengaruh pemberian kompres hangat terhadap nyeri persendian Osteoartritis pada lanjut usia di Panti Wredha Dharma Ponggalan Umbulharjo Yogyakarta. Doctoral dissertation, STIKES'Aisyiyah Yogyakarta. Diperoleh pada tanggal 20 juni 2019 dari https://digilib.unisayogya.ac.id
Wurangian. (2014). Pengaruh kompres hangat terhadap penurunan skala nyeri pada penderita Gout Arthitis di Wilayah Kerja Puskesmas Bahu, Menado. Jurnal e-Biomedik, ejournalunsrat.ac.id 